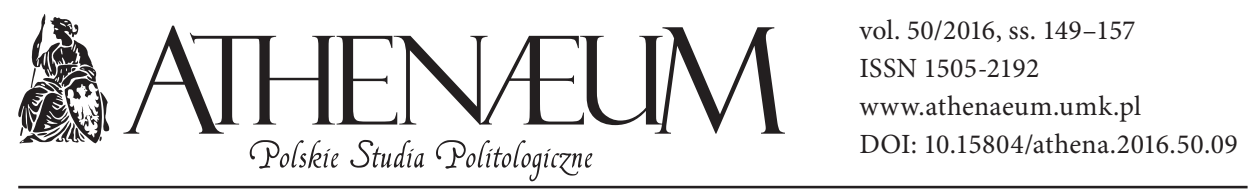

\title{
ZNACZENIE IRAŃSKIEJ OPOZYCJI ANTYREŻIMOWEJ DLA POLITYKI ZAGRANICZNEJ BARACKA OBAMY
}

\author{
THE MEANING OF THE IRANIAN ANTI-REGIME OPPOSITION \\ FOR THE FOREIGN POLICY OF BARACK OBAMA
}

Maciej Milczanowski*

\begin{abstract}
ABSTRAKT
Od 1979 roku reżim irański jest w zasadniczym konflikcie ze światem Zachodu, a szczególnie z USA i Wielką Brytanią oraz Izraelem. W tak długim okresie dochodziło do okresowych zmian, z którymi administracja USA wiązała pewne nadzieje. Niemniej jednak, mimo chwilowych okresów pozornej odwilży w stosunkach dwustronnych, za każdym razem następował powrót do tradycyjnej wrogości między Islamską Republiką Iranu a USA. Jednocześnie społeczeństwo irańskie jest narażone na nieustanne represje ze strony władz. Zachodzi więc zasadnicze pytanie, w jaki sposób i czy w ogóle Zachód, a przede wszystkim USA jako mocarstwo globalne, o największym potencjale militarno-operacyjnym pozwalającym na oddziaływanie w każdym rejonie świata, powinny reagować na sytuację i wydarzenia w Iranie.

Celem artykułu jest poddanie analizie charakteru oraz sposobów działania najważniejszych irańskich grup opozycyjnych, a także ich znaczenia dla programu politycznego USA zawartego w tzw. doktrynie Obamy (2009). Analiza najważniej-
\end{abstract}

Since 1979, the Iranian regime is in a fundamental conflict with the Western world, especially the US, Britain, and Israel. In such a long period, there have to be periodic changes which the US administration had some high hopes for. However, despite temporary periods of apparent thaw in bilateral relations, each time it is followed by a return to the traditional hostility between the Islamic Republic of Iran and the United States. At the same time, Iranian society is exposed to constant repression from the authorities. There is, therefore, a fundamental question, how, or even if, the West, and primarily the US as a global power, with the biggest military and operational potential, allowing for interaction in every region of the world, should react to the situation and developments in Iran.

The aim of the article is to review the nature and methods of operation of main Iranian opposition groups as well as their significance for the political program contained in the so-called Obama's doctrine (2009). Analysis of major opposition groups will determine the degree of their pos-

* Wyższa Szkoła Informatyki i Zarządzania w Rzeszowie, Katedra Bezpieczeństwa Wewnętrznego. 
szych grup opozycyjnych pozwoli na określenie stopnia możliwej ich współpracy z USA, jak i ich potencjału do sprawowania władzy w Iranie w sposób jak najbardziej demokratyczny.

Słowa kluczowe: Iran, USA, opozycja, polityka międzynarodowa, konflikt międzynarodowy sible cooperation with the US and their capacity to exercise power in Iran in the most democratic way.

Keywords: Iran, USA, opposition, international policy, international conflict

\section{SMART POWER BARACKA OBAMY I IRAN}

Już w 2004 roku prof. Joseph Ney (2004) zaproponował oparcie polityki USA na koncepcji Smart Power (Milczanowski, 2014) Koncepcja ta została określona podstawą polityki zagranicznej w czasie prezydentury Baracka Obamy. W jego administracji sekretarzem stanu została Hillary Clinton, która już w trakcie wstępnego przesłuchania na to stanowisko określiła zasady funkcjonowania nowej doktryny bezpieczeństwa narodowego jako w pełni opartej na Smart Power. H. Clinton (2009). Koncepcję tę wyjaśniała następująco: „[...] pełen wachlarz narzędzi w naszej dyspozycji - dyplomatycznych, ekonomicznych, wojskowych, politycznych, prawnych i kulturowych - wybór właściwego narzędzia lub kombinacji narzędzi, stosowanie dla danej sytuacji. Zgodnie ze Smart Policy, dyplomacja będzie podstawą polityki zagranicznej [...]"1. Koncepcja ta polega na wykorzystaniu szerokiej palety dostępnych narzędzi, zaliczanych do Hard Power z jednej, a także Soft Power z drugiej strony. Określenie smart ma oznaczać dobór i odpowiednie zestawianie różnych narzędzi w najwłaściwszy sposób w zależności od wielu czynników (Nye, 2004).

Pierwsze lata prezydentury Baracka Obamy były bardzo obiecujące. USA wycofały wojska z Iraku, próbowały nawiązać nowe relacje z Rosją i Iranem, pierwsze publiczne wystąpienia prezydenta USA zyskiwały mu wielu sympatyków na całym świecie. Barack Obama bardzo starał się udowodnić, że jest zupełnie innym prezydentem niż jego poprzednik na tym stanowisku, czego konsekwencją miało być stosowanie Smart Power zamiast środków militarnych. Barack Obama zaczął realizację swojego programu poprawy relacji z Iranem (Shahram Akbarzadeh, 2011) od wystosowania przesłania do narodu irańskiego

\footnotetext{
${ }^{1},[\ldots]$ the full range of tools at our disposal - diplomatic, economic, military, political, legal, and cultural - picking the right tool, or combination of tools, for each situation. With smart power, diplomacy will be the vanguard of foreign policy $[\ldots]$ ".
} 
oraz rządzących tym państwem (Obama, 2009b; 2014). Prezydent obiecywał odmrożenie stosunków bezpośrednich z przywódcami Iranu. Przemówienie w Kairze (2009a) było symboliczne dla nowej doktryny prezentowanej przez prezydenta Obamę. Jednocześnie jako Hard Power administracja Stanów Zjednoczonych rozwijała działania związane z tzw. track two diplomacy (Agha, Feldman, Khalidi, Schiff, 2003). Prowadzono programy globalnej inwigilacji, szpiegując nawet delegatów państw w ONZ czy prywatne telefony przywódców państw sojuszniczych. USA wycofywały się z bezpośrednich działań militarnych, ale $\mathrm{w}$ to miejsce znacznie rozwinęły operacje nieoficjalne prowadzone za pomocą tzw. UFV (Unmaned Flying Vehicles), bezzałogowych statków latających, popularnie zwanymi dronami, operacji oddziałów wojsk specjalnych czy też służb wywiadowczych.

Tak więc w istocie działania obu prezydentów sprawujących swój urząd po 11 września 2001 opierały się w dużej mierze na Hard Power, szczególnie w tzw. wojnie z terroryzmem. Soft Power stała się jednak narzędziem do naprawiania relacji międzynarodowych USA w czasie prezydentury Baracka Obamy. Wprawdzie niekwestionowana dominacja militarna ( $w$ tym też globalny monopol na dostęp do informacji) USA na świecie sprawia, że państwo to może obrać taką doktrynę, jaką zechce, jednak nawet dla tak potężnego państwa skutki błędnych działań są bardzo znaczące. Sposób prowadzenia operacji militarno-politycznych w Afganistanie i Iraku rozpoczętych przez prezydenta Georga W. Busha stworzył takie okoliczności, które zmusiły następnego prezydenta do radykalnej zmiany polityki USA przechodzącej z Hard do Soft Power. Mimo tego, że prezydent Obama pochodzi z obozu demokratycznego, część jego działań na Bliskim Wschodzie nadal oparta jest na środkach militarnych.

\section{OPOZYCJA ANTYREŻIMOWA W IRANIE}

Analiza grup opozycyjnych w Iranie stwarza szereg trudności. Z jednej strony grupy te są mocno podzielone i często wrogo do siebie nastawione, a $z$ drugiej wszystkie grupy opozycyjne dokładają wszelkich starań, aby ich wizerunek był jak najbardziej dostosowany do wzorców demokratycznych, nawet zachodnich. Jedne są silnie infiltrowane lub nawet sterowane przez reżim, udając jedynie opozycję, a inne z kolei popadają w radykalizm, który w razie objęcia przez nie władzy stanowiłby zapewne większe zagrożenie dla mieszkańców Iranu niż władza mułłów. 
Jedną z najlepiej zorganizowanych organizacji antyreżimowych jest Mujahedeen e-Khalq (MeK) nazywana też People’s Mojahedin of Iran (PMoI). Organizacja została założona przez Masuda Radżawiego i jest prowadzona przez niego i jego żonę Marjam Radżawi. Organizacja ta była uznawana za terrorystyczną od 1997 roku i stało się to wtedy, gdy urząd prezydenta obejmował w Iranie Mohammad Chatami uznawany za reformatora. Wprowadzenie na listę organizacji terrorystycznych skrajnie wrogiej władzom Iranu MeK wyglądało raczej na gest dobrej woli ze strony administracji USA w celu ocieplenia stosunków z nowymi władzami Iranu. Niemniej jednak, sposób działania MeK, jak i funkcjonowanie tej grupy jest zbliżone raczej do sekty niż do organizacji o demokratycznych fundamentach (Rubin, 2003). Niezależnie od charakteru tej grupy, w 2003 roku jej członkowie zamieszkujący w Iraku w Camp Ashraf otrzymali od władz USA gwarancje bezpieczeństwa. Jednakże, gdy wojska koalicyjne wycofały się z Iraku, władze tego państwa zdominowane przez Szyitów, z premierem Nurim Al-Malikim na czele, podjęły kilkakrotnie próby rozbicia tej grupy. Momentem kulminacyjnym akcji przeciw Camp Ashraf był dzień 1 sierpnia 2013, gdy uzbrojona grupa ludzi wdarła się do obozu, zabijając 52 osoby (NCRI, 2013; NCRI 2014). Wydarzenia te stały się jedną z przyczyn usunięcia MeK z listy organizacji terrorystycznych FTO (Foreign Terrorist Organizations) (Bahgat, 2004).

Komórki MeK są rozsiane po całej Europie Zachodniej - najważniejsza siedziba znajduje się we Francji oraz w USA. Na bazie tej organizacji stworzono też National Council of Resistance of Iran (NCR-I). Ze strony internetowej tego sojuszu organizacji opozycyjnych można dowiedzieć się, że jest to modelowa struktura demokratyczna, stanowiąca rodzaj parlamentu działającego na uchodźctwie, składająca się w połowie z kobiet, mniejszości religijnych i etnicznych w Iranie (Żydzi, chrześcijanie, Kurdowie, sunnici). Organizacja ta ma też stosować jedynie pokojowe metody działania w celu zmiany sytuacji w Iranie ${ }^{2}$. Taki sposób autoprezentacji powodował sympatię wielu środowisk zachodnich dla tej inicjatywy. Niestety istnieją świadectwa świadczące o zupełnie innym charakterze tej organizacji. Wynika z nich, że jest to raczej rodzaj sekty, w której stosowana jest tzw. silna indoktrynacja już wśród dzieci, które separuje się od rodziców. Dzieci te są wychowywane w duchu zupełnego posłuszeństwa władzom organizacji, a szczególnie Marjam Radżawi. Członkowie tej organizacji nie integrują się ze społeczeństwami krajów, w których przebywają. Zamiast tego zakładają szkoły z programem nauczania dostosowanym do systemu totalnej

\footnotetext{
${ }^{2}$ http://www.ncr-iran.org/en/about/our-resistance, 26.09.2014.
} 
indoktrynacji. W efekcie organizacja ta przygotowuje ślepo posłusznych woli Radżawi członków, którzy są gotowi do każdego poświęcenia dla swojej liderki. W tej sytuacji wspieranie organizacji o takiej charakterystyce stanowi wielkie zagrożenie, zarówno dla Zachodu, jak i przede wszystkim dla samych Irańczyków (HRW, 2005; RAND, 2009; Rubin, 2003).

Innymi organizacjami istotnymi dla relacji między USA a Iranem są: National Iranian American Council (NIAC), zwana też American Iranian Council (AIC) ${ }^{3}$. Organizacja ta założona w USA, za główne zadanie stawia sobie poprawienie relacji amerykańsko-irańskich. Jej liderzy utrzymują, że Iran to państwo zupełnie demokratyczne i wolne, stawiając na tym samym poziomie sytuację społeczno-polityczną Iranu i USA. W sytuacji rosnącej w 2013 i 2014 roku liczby egzekucji, ograniczania praw człowieka i w końcówce roku 2014 akcji, na którą władze nie reagowały, a w której kobiety ubierające się niewystarczająco stosownie są celem ataków, w wyniku których są brutalnie okaleczane, twierdzenie, że Iran jest państwem wolnym, jest mało wiarygodne. Organizacja ta jest więc raczej ekspozyturą i ośrodkiem propagandowym władz irańskich, będąc jednocześnie finansowaną też ze źródeł amerykańskich.

Jedyną organizacją - czy raczej ruchem obywatelskim, o znaczącej sile i z celem demokratyzacji Iranu, wydaje się tzw. Green Movement (GM). Liderzy GM dystansują się zdecydowanie od MeK z dwóch powodów. Po pierwsze GM działa głównie w samym Iranie. Dlatego jakiekolwiek powiązania z radykalną $\mathrm{MeK}^{4}$, koncentrowałyby uwagę władz na GM. Z drugiej strony MeK oskarża wszystkie organizacje, które nie współpracują z nimi, o zdradę i kolaborację z władzami Iranu i w szczególny sposób tyczy się to właśnie GM. Z pewnością jest w tym część prawdy, bowiem GM nie jest w stanie uniknąć infiltracji, działając w państwie rządzonym przez reżim religijny, jednak to nie neguje opozycyjności całego ruchu. Zarówno władze Iranu, jak i NIAC są skłonne oskarżać GM o współpracę z MeK, gdyż to pomaga zwracać społeczeństwo Iranu przeciw GM, a właśnie brak poparcia społecznego najbardziej osłabia opozycję. GM odgrywa jednak także pewną rolę w bieżącej polityce Iranu, bowiem prezydent wybrany w 2013 roku, Hasan Rouhani, jako jedno ze swoich haseł wyborczych ogłosił obietnicę działań na rzecz uwolnienia z aresztu domowego dwóch liderów GM: Mirhossein Mousavi oraz Mahdi Karrubi, aresztowanych wraz z dwoma innymi przywódcami ruchu GM (Hoseinem-Ali Montazerim oraz Mohamadem Khatamim) w wyniku

\footnotetext{
${ }^{3}$ http://www.iran-resist.org/article5067.html.

${ }^{4}$ http://www.salon.com/2011/03/26/iran_green_movement/.
} 
protestów przeciw, ich zdaniem, sfałszowanym wyborom w 2009 roku (Aseman Daily News, 2009). Jednakże gra polityczna wewnątrz Iranu jest bardzo zawiła i dlatego nie należy zarówno zbytnio ufać prezydentowi w jego umiarkowanie w sprawowaniu władzy, ani też obaj liderzy GM nie cieszą się zaufaniem całego ruchu, nie wspominając o reszcie społeczeństwa. Podnoszona jest kwestia funkcjonowania obu liderów GM we władzach Iranu, współtworząc reżim (Ganji, 2014). Mało wiarygodny jest też prezydent Rouhani, który stara się wykreować fałszywy obraz walki politycznej w Iranie, w którym po jednej stronie stawia tzw. liberałów, ze sobą na czele, i w tej samej linii obu liderów GM, a po drugiej stronie, jako „twardogłowych”, konserwatystów - którymi mają być zwolennicy najwyższego przywódcy Iranu ajatollaha Ruhollaha Chomeiniego. Obecny najwyższy przywódca Iranu - ajatollah Ali Chamenei, nie jest tu wymieniany w żadnym obozie, co także wskazuje na faktyczne intencje prezydenta Rouhaniego. Prawdziwa siła GM tkwi jednak nie w liderach, ale w ogromnym społecznym poparciu tego ruchu w Iranie, co ujawniło się z całą siłą w 2009 roku podczas manifestacji przeciw sfałszowanym (zdaniem liderów GM) wyborom, w których zwyciężył Mahmud Ahmadineżad (Khalaji, Clawson, Singh, Sazegara, 2009).

Grupa opozycyjna o mniejszym poparciu wśród Irańczyków, ale też ważna z politycznego punktu widzenia to Iranian National Council z Rezą Pahlawim. Pahlawi jest najstarszym synem byłego szacha Iranu, który został zmuszony do ucieczki w wyniku rewolucji islamskiej. Obecnie nie rości on sobie prawa do tytułów, jakie mogłyby mu się należeć jako następcy tronu, lecz raczej pozuje na lidera jednego z ugrupowań w ramach demokratycznej rywalizacji (Pahlavi, $2014)^{5}$. Oczywiście jego sytuacja jest bardzo skomplikowana wskutek tego, w jaki sposób jego ojciec sprawował władzę w Iranie. Niemniej jego działania świadczą zarówno o możliwościach porozumienia z innymi grupami opozycyjnymi, jak i umiejętności gromadzenia poparcia społecznego. Słabością Pahlaviego jest jednak to, że nie ma praktycznie żadnych możliwości działania na terenie własnego kraju.

\section{WNIOSKI}

Barack Obama, tak jak zapowiadał, od początku swojej prezydentury próbował ocieplić relacje z reżimem w Iranie (Sick, 2009). Niemniej jednak władze w Teheranie były skłonne do wysyłania porozumiewawczych sygnałów tylko wtedy,

${ }^{5}$ http://www.rezapahlavi.org. 
gdy skłaniała ich do tego wewnętrzna sytuacja. Dlatego też gdy spacyfikowano demonstracje po wyborach w 2009 roku, relacje irańsko-amerykańskie stały się znów wrogie (Porter, 2009). Mimo więc planu rozprężenia stosunków irańsko-amerykańskich USA pozostały przy sankcjach i izolowaniu Iranu (Leyne, 2010; Kaussler 2012).

W negocjacjach z Iranem istotne jest to, że realną władzę posiada Najwyższy przywódca duchowny oraz zależnie od sytuacji tzw. Korpus Strażników Rewolucji (Safshekan, Sabet, 2010; Blanche 2014). Prezydent jest od nich zupełnie zależny. Pomiędzy tymi ośrodkami władzy istnieje więc raczej współpraca, a nie rywalizacja, ani też prezydent nie ma możliwości kontrolowania przywódcy duchowego Iranu, ani Korpusu Strażników Rewolucji. Właśnie dlatego opozycja powinna stanowić punkt odniesienia dla przywódców USA, chcących odgrywać rolę polityczną na Bliskim Wschodzie. W negocjacjach $\mathrm{z}$ Iranem należy więc uwzględnić analizy reżimu dokonywane przez poszczególne grupy opozycyjne. Jednakże pozyskiwane i przekazywane przez nie informacje muszą być stosownie weryfikowane, gdyż każda $z$ nich ma swoje własne cele i motywy. Zarówno osłabianie reżimu w Iranie poprzez dalszą izolację, jak i wzmacnianie przez ewentualną współpracę ( $w$ wyniku ewentualnego porozumienia nuklearnego lub przy zwalczaniu ISIS) mogą powodować podobnie negatywne skutki. Przejęcie władzy w Iranie przez MeK czy NIAC lub utrzymywanie władzy przez ajatollahów w sytuacji słabnącej gospodarki i rosnącego niezadowolenia społecznego tak samo mogą doprowadzić kraj nad przepaść. Zarówno więc prowadzenie negocjacji z Iranem, gdzie jedynym priorytetem jest zatrzymanie programu nuklearnego prowadzonego w celach wojskowych (Cooper, Landler, 2009), jak i finansowanie ugrupowań będących ekspozyturami władz irańskich czy radykałów o metodach działań zbliżonych do sekty, stanowią przejaw i są jednocześnie wynikiem symplifikacji całego problemu, a także przejawem braku przeglądu sytuacji geopolitycznej, co wcześniej doprowadziło zachodniego sąsiada Iranu do upadku.

Co bardzo istotne, właśnie przykład Iraku, ale też Libii, Syrii czy Afganistanu powoduje, że żadne z liczących się ugrupowań opozycyjnych nie ma na celu sprowokowania interwencji militarnej w celu obalenia reżimu sprawującego władzę w Iranie (Ganji, 2014). Reza Pahlawi w jednym z wywiadów przedstawia nawet polski model zmiany systemu politycznego z końcówki lat 80., jako optymalny - także dla Iranu (Pahlavi 2013). Operacja militarna byłaby katastrofą nie tylko dla Iranu, musiałaby mieć też bardzo negatywne konsekwencje dla całego regionu. W tym przypadku umiarkowana polityka prezydenta Obamy, 
który stosuje intensywne negocjacje i działania w ramach tzw. „track two diplomacy”, a także utrzymywanie dotkliwych sankcji, jak również ingerencje w rynek paliw powodujące obniżenie ceny ropy, od której w dużej mierze uzależniony jest reżim irański, są - jak się wydaje - jedyną drogą do wywarcia wpływu na władze i zmuszenia ich do zmiany polityki zarówno wewnętrznej, jak i regionalnej. Kontrowersje może natomiast wzbudzać sposób realizacji tych założeń i ich skuteczność. Jakkolwiek metody dyplomatyczne niemal zawsze są lepsze of konfliktu zbrojnego, dlatego negocjacje z Iranem i próby zawarcia porozumienia powinny być odbierane pozytywnie, to jednak rola grup opozycyjnych, a także wsparcia dla Green Movement, wydaje się niedostateczna. Z drugiej strony wydaje się, że duże wsparcie organizacyjne i finansowe dla MeK i NIAC oraz NCRI nie przynosi żadnej korzyści jedynej umiarkowanej opozycji - czyli GM.

\section{BIBLIOGRAFIA:}

Agha, A. Feldman, S. Khalidi, A. Schiff, Z. (2003). Track-II Diplomacy. Cambridge, MA: MIT Press.

Akbarzadeh, S. (2011). Democracy Promotion versus Engagement with Iran. Journal of Contemporary Asia, Vol. 41, No. 3, August, pp. 470-482

Aseman Daily News (2009). (w jęz. perskim) z dnia 5 lipca.

Bahgat, G. (2004). The War on Terrorism: The Mujahedeen e-Khalk Saga. Studies in Conflict \& Terrorism, vol. 27, 2004, pp 377-385.

Blanche, E. (2014). Rouhani vs Revolutionary Guards'. The Middle East, March.

Clinton, H.R. (2009). Nomination Hearing To Be Secretary of State, Senate Foreign Relations Committee Washington, DC. Pobrane z: https://www.state.gov/secretary/ $\mathrm{rm} / 2009 \mathrm{a} / 01 / 115196 . \mathrm{htm}$.

Cooper, H. Landler, M. (2009). For Obama, Pressure to Strike Firmer Tone. New York Times, June 18.

Ganji, A. (2014). Iran's Green Movement Five Years Later: Defeated'But Ultimately Victorious. Pobrano z: http://www.huffingtonpost.com/akbar-ganji/iran-green-movement-five-years_b_5470078.html.

HRW. (2005). Human Rights Watch, No Exit: Human Rights Abuses Inside the Mojahedin Khalq Camps. Pobrano z: http://www.unhcr.org/refworld/docid/45d085002.html. http://www.iran-resist.org/article5067.html (accessed 10.09.2014).

http://www.salon.com/2011/03/26/iran_green_movement/ (accessed 10.09.2014).

Kaussler, B. Newkirk, A.B. (2012). Diplomacy in Bad Faith: American-Iranian Relations Today. Diplomacy \& Statecraft, 23, s. 366-367.

Khalaji, M; Clawson, P; Singh, M; Sazegara, M. (2009). Iran's 'Election': What Happened? What Does It Mean?, Washington Institute for Near East Policy, Policy Watch \#1537: Special Policy Forum Report. 
Leyne, J. (2010). Iran Hit by Fresh UN Nuclear Sanctions Threat, BBC. Pobrano z: http:// www.bbc.co.uk/news/10124238.

Milczanowski, M. (2014). Smart Power and the golden mean in US policy, My Point of View. Pobrano z: http://mmilczanowski.wordpress.com/2014/09/23/smart-power-and-the-golden-mean-in-us-policy/.

NCRI. (2013). US-UN-MEK: Kill the messenger not the dictator. Pobrane z: http:// www.ncr-iran.org/en/camp-ashraf-massacre-sept-2013/15225-us-un-mek-kill-themessenger-not-the-dictator.

NCRI. (2014). Five years after massacre at Camp Ashraf on July 28-29. Pobrane z: http://www.ncr-iran.org/en/news/ashraf-liberty/16904-five-years-after-massacreat-camp-ashraf-on-july-28-29-2009.

Nye, Jr. J.S. (2004). Soft Power: The Means To Success In World Politics, New York.

Obama, B. (2014). President Obama's Nowruz Message to the Iranian People, The White House. Pobrane z: http://www.whitehouse.gov/photos-and-video/ video/2014/03/20/president-obama-s-nowruz-message-iranian-people.

Obama, B. (2009a). A New Beginning, Remarks Cairo University. Speech in Cairo: Egypt. Pobrane z: http://www.state.gov/p/nea/rls/rm/2009/124342.htm.

Obama, B. (2009b). The President's Message to the Iranian People, The White House. Pobrane z: https://www.youtube.com/watch?v=HY_utC-hrjI\&ab_channel=TheWhiteHouse.

Pahlavi, R. (2014). Iran's Future - BBC Presenter Huw Edwards Interviews Prince Reza Pahlavi. Pobrano z: http://www.rezapahlavi.org.

Porter, G. (2009). Obama’s Iranian Discontent, Agence Global.

RAND Corporation, The Mujahedin-e Khalq in Iraq: A Policy Conundrum. Pobrano z: http://www.rand.org/content/dam/rand/pubs/monographs/2009/RAND_MG871. pdf.

Renshon, S.A. (2010). National Security in the Obama Administration: Reassessing the Bush Doctrine, New York, s. 5.

Rubin, E. The Cult of Rajavi, The New York Times, July 13, 2003.

Safshekan, R. Sabet, F. (2010). The Ayatollah's Praetorians: The Islamic Revolutionary Guard Corps and the 2009 Election Crisis, Middle East Journal, Vol. 64, No. 4.

Sick, G. (2009). Real Progress with Iran, Daily Beast. Pobrano z: www.thedailybeast. com/articles/2009/10/02/real-progress-with-iran.html.

Pahlavi, R. (2013). Iran National Council, BBC HARDtalk. Pobrano z: https://www. youtube.com/watch? $\mathrm{v}=4 \mathrm{~N} 7 \mathrm{E} 4 \mathrm{oalce}$.

Gause, F.G. III; Lustick, I.S. (2012). America and the Regional Powers in a Transforming Middle East. Middle East Policy, Vol. 19, No. 2, s. 1-9. 